\title{
A LOOK AT THE LIFE PATH OF FATTOKHON MAMADALIEV
}

\author{
Ijodbek Jurayev
}

Teacher, Fergana Regional Branch Of Uzbekistan State Institute Of Arts And Culture, Uzbekistan

\section{ABSTRACT}

The article tells about the life and work of Fattokhon Mamadaliev, an Uzbek People's Artist, known for his fruitful works and performances. Folk art is a huge and enormous world. It is constantly enriched with the products of the creative people and is constantly expanding. After all, every specimen in this ocean is explained by its own mysteries, national traditions, national psyche and national values. This is the main basis for the formation and development of Uzbek national music and literature. When we look at our past, we can see that it occupies a light-scattering place, how ancient the art of music is, it is a golden treasure in the lives of our ancestors, in the lives of world-renowned scientists, thinkers and scientists, in the lives of the most advanced people of their time, in their immortal creativity, research and vision.

KEYWORDS:- Fattohkhon Mamadaliyev, Nasrulloyi, Miskin, Etmasmidim, Jononim mening, Intizor, Kongil, Oqibat, Kokiling, Dilkusho, Qalandar-1, Mogilchai kashkarchai ushshak, Girya, Ey sabo.

\section{INTRODUCTION}

It is safe to say that the great cultural and spiritual significance of the Uzbek classical music heritage lies in its traditions. Because classical music, by its very name, embodies all the traditions associated with the formation and development of professional music. The unique creative heritage and traditions of folk composers, as a creative product of values, have been perfected in the work of unique musicians and singers. The teacher-student relationship has been the most important criterion and key factor in the transmission of traditions from generation to generation. As we know, some of the artists who have matured in the past and become teachers have managed to create their own style of performance, and some of them have created their own school. Such performing schools, created in the Uzbek professional music and performance, are distinguished not only by their tradition, but also by their originality. We,
Hodjihon Boltaev or Madrahim Sheroziy, Domla Halim Ibodov, Toshpulatov, Mulla Toychi Tashmuhamedov or Yunus Rajabiy, Fattohkhon Mamadaliyev, Jurahon Sultanov or Rasul qori Mamadaliyev, Muhammadjon Karimov or Orifkhon Hotamov as an example we can admit. Let's take a closer look at the life and work of Fattokhon Mamadaliev, the honored son of the Uzbek people.

When we say Fattokhon Mamadaliyev, we mean a rare voice of a traditional singer, a beloved artist, a charming singer who has created a unique style and way of performing in the world of singing. The sadness in the teacher's voice, the loud moans, the resonant features do not leave the listener indifferent. Fattohkhon Mamadaliyev was born in 1923 in the old village of Khalkulabad, Balikchi district, Andijan region. From a young age, he was fascinated by singing and art, and learned to sing with a violin. A wellknown hafiz and musician, Umrzak Saidloniyev, who was aware of his talent, became an 
CURRENT RESEARCH JOURNAL OF PEDAGOGICS 2(11): 54-59, November

2021 DOI: https://doi.org/10.37547/pedagogics-crjp-02-11-12

ISSN 2767-3278

(C)2021 Master Journals

Crossref do: 81 Google

Accepted 25th November, 2021 \& Published 30 ${ }^{\text {th }}$ November, 2021

apprentice, and his fame gradually spread to Khalkulabad. The period of true hafiz began when he came to Andijan, lived and worked there. He was a member of the maqom ensemble at the Andijan City House of Culture and later worked as an art director for many years. Hamnafas created a series of songs with his friend Yuldashali Kiyikov. The songs they sang in unison were recorded on the national radio. Fattokhon Mamadaliev's arrival in Tashkent marked an important turning point in his career. New songs are born. He compiled a scientific performance analysis of the Fergana-Tashkent maqom way and taught it to his students. His work in the ensemble of maqoms under the Republican Television and Radio Company, combined with his scientific and pedagogical work at the State Philharmonic and the Department of Traditional Performance at the Tashkent State Conservatory, yielded positive results. Another great contribution of Fattokhon Mamadaliev is that he has re-analyzed and restored a number of performances, one of the rare masterpieces of our people's art. In particular, "Nasrulloyi" spoke about the music and created its interpretation, euphoria, chronology. He restored the ancient performances of the Ushaks by adding the five lines of the Miskin, the five lines of the Chorgoh, and the memoirs of the Umrzaqpolvon Ushshak. Interpreted Buzruk's trumpet ways. As a result of the research, it was recognized by our performers and scholars as "Savti Fattohkhan" as a series. In collaboration with musicologist Ravshan Yunusov, he made a scientific analysis of the above-mentioned ways of performing and published a pamphlet "Issues of National Music Performance." Master Yunus Rajabi did a lot of unfinished work. Most importantly, he taught his students the results of all this research and sealed them on magnetic tape. Fattokhon Mamadaliyev's "Etmasmidim", "Jononim mening", "Intizor", "Kongil", "Oqibat", "Kokiling",
"Dilkusho", "Qalandar-I", "Mogulchai kashkarchai ushshak" Songs such as "Girya", "Ey sabo" won the hearts of fans with their specially designed and performed. The song "Dardu dilim" performed by him took an honorable place in the festival competition of the scientific conference "Asian Music Tribune" in the Republic of Mongolia. Fattokhon Mamadaliyev has captivated dozens of foreign singers with his melodious voice. He was on a pilgrimage. Another bright side of his work was his acquaintance with poetry.

Ey sabo, holim borib sarvi xiromonimg'a ayt,

Yig'larimning shiddatin gulbargi xandonimg'a ayt.

Buki aning ahdu paymonida men o'lsam dag'i

Yaxshi fursat topsang, ul bad'ahdu paymonimg'a ayt.

Buki aning zulfi zunnorida dinim hosili

Kufr ila bo'lmish mubaddal nomusulmonimg'a ayt.

Buki qilmishmen jahonu jonni aning sadqasi,

Yuz tuman jonu jahondin yaxshi jononimg'a ayt.

Buki yuz jon sadqasi qilsam pushaymon bo'lma g'um,

Vasli g'a bir va'da qil g'andin pushaymonimg'a ayt.

Buki yuz ming fitnako'zlug bo'lsa paydo onsizin,

Qilma g'um nazzora hargiz ko'zi fattonimg'a ayt.

Buki chok aylab yoqa, usruk chiqar el qasdi g'a,

Men o'lib el jon topar, bebok nodonimg'a ayt.

Dahr bog'i gullari husnin vafosiz erkanin,

Yuzi gul, jismi suman, ko'yi gulistonimg'a ayt.

Ey Navoiy, hech gulshanning seningdek xushnavo

Bulbuli yo‘q erkanin shohi suxandonimg'a ayt. 
CURRENT RESEARCH JOURNAL OF PEDAGOGICS 2(11): 54-59, November

2021 DOI: https://doi.org/10.37547/pedagogics-crjp-02-11-12

ISSN 2767-3278

(C)2021 Master Journals

Crossref do: 81 Google

Accepted $25^{\text {th }}$ November, 2021 \& Published $30^{\text {th }}$ November, 2021

He wrote beautiful poems and composed melodies himself. He was a member of the Union of Composers of Uzbekistan. His services have been deservedly rewarded by our government, especially during the years of independence. Recognition of the honorary titles of "Honored Artist of Uzbekistan", "Honored Hafiz of Uzbekistan", "Mehnat Shuhrati", "El-Yurt Hurmati", and Professor of the Tashkent State Conservatory is a real appreciation of the teacher's services. Remarkabl singer Fattohkhon Mamadaliyev died on April 4, 1999 after a serious illness and was buried in his native village.

\section{REFERENCES}

1. Yunusov, G., Juraev, I., \& Ahmedov, R. (2020). A LOOK AT THE REGIONAL SEASONAL FOLKLORE AND THEIR ORIGIN. THE ROLE AND IMPORTANCE OF FOLKLORE IN THE DEVELOPMENT OF DANCE ART. European Journal of Arts, (1), 121-124.

2. Yunusov, G., Ahmedov, R., Jurayev, I., \& Yuldasheva, S. (2021). A Look At The Folklore of Fergana Valley or History of A Song in The Series of Tanovar. Annals of the Romanian Society for Cell Biology, 25(6), 2225-2232.

3. Talaboev, A., Akbarov, T., \& Haydarov, A. The European Journal of Arts, Issue $1 / 2020$.

4. Boltaboeva, U., Abdunazarov, Z., \& Usmonov, S. (2021). The balance of language and speech in the Uzbek theater. ASIAN JOURNAL OF MULTIDIMENSIONAL RESEARCH, 10(4), 788-792.

5. Абдуназаров, 3. (2021). ИЖОДИЙ СИНТЕЗ ЖАРАЁНЛАРИНИ ТАШКИЛ ЭТИШДА РЕЖИССЁРНИНГ РОЛИ. Oriental Art and Culture, (6).
6. Haydarov, A., Akbarov, T., \& Abdunazarov, Z. (2020). High purpose and leading action. ACADEMICIA: AN INTERNATIONAL MULTIDISCIPLINARY RESEARCH JOURNAL, 10(12), 609-615.

7. Akbarova, M., Tursunova, G., \& Abdunazarov, Z. (2020). Pedagogical aproaches to the formation of musical literacy of students in the sytem of Higher Education. European Journal of Arts, (1), 125-128.

8. Абдуназаров, 3. (2020). Тимсоллар сиймосини яратиш. Oriental Art and Culture, (III), 146-150.

9. Абдуназаров, 3. (2020). Миллий ўйинларимиз иштирокида ёш актёрларни тасаввури ва диққатини чархлаш. Oriental Art and Culture, (III), 134-138.

10. Akbarova, M., Tursunova, G., \& Abdunazarov, Z. (2020). Pedagogical aproaches to the formation of musical literacy of students in the sytem of Higher Education. European Journal of Arts, (1), 125-128.

11. Болтабоева, У. (2020). ҚЎғИРЧОҚ ТЕАТРИ ГУРУХЛАРИДА САХНАВИЙ НУТҚНИНГ АХАМИЯТИ. Oriental Art and Culture, 1(5), 85-92.

12. Boltaboeva, U., Gofurova, B., Pulatov, R., \& Mamatkulov, B. (2020). Methods of improving the young actors speech. ACADEMICIA: AN INTERNATIONAL MULTIDISCIPLINARY RESEARCH JOURNAL, 10(12), 1114-1123.

13. Болтабоева, У. (2021). МУСИҚАЛИ ДРАМА ТЕАТРЛАРИНИНГ РИВОЖЛАНИШИДА ТАРИХИЙ АСАРЛАРНИНГ РОЛИ. Oriental Art and Culture, (6). 
CURRENT RESEARCH JOURNAL OF PEDAGOGICS 2(11): 54-59, November

2021 DOI: https://doi.org/10.37547/pedagogics-crjp-02-11-12

ISSN 2767-3278

(C)2021 Master Journals

Crossref do) 81 Google

Accepted $25^{\text {th }}$ November, 2021 \& Published $30^{\text {th }}$ November, 2021

14. Эргашев, К., \& Болтабоева, У. (2021). УЧИНЧИ РЕНЕССАНС ЁШЛАР НИГОХИДА. Oriental Art and Culture, (6).

15. Болтабоева, У. (2021). ЎЗБЕК ТЕАТРИ САХНАЛАРИДА ТИЛ ВА НУТҚ МУТАНОСИБЛИГИ. Oriental Art and Culture, (7), 171-180.

16. Boltaboeva, U., Abdunazarov, Z., \& Usmonov, S. (2021). The balance of language and speech in the Uzbek theater. ASIAN JOURNAL OF MULTIDIMENSIONAL RESEARCH, 10(4), 788-792.

17. Usmonov, S., Boltaboeva, U., \& Akbarov, T. (2021). Principles of working on a monologue with future actors. Asian Journal of Multidimensional Research, 10(6), 28-38.

18. Boltaboeva, U., Usmonov, S., \& Akbarov, T. (2021). A Look at Askia Art. Annals of the Romanian Society for Cell Biology, 25(6), 2277-2284.

19. Usmonov, S., Boltaboeva, U., Rahmonova, N., \& Akbarov, T. (2021). Pedagogical Approaches To Educating Future Actors. The American Journal of Interdisciplinary Innovations Research, 3(05), 85-90.

20. Болтабоева, У. (2019). Ижодкор шахсактёрни тарбиялашда жонли сўзнинг ўрни. Oriental Art and Culture, (IV (1)), 37-39.

21. Рахматуллаева, Ш., Болтабоева, У., \& Каримов, Б. (2019). Фольклор санъати ва халқ достонлари: кеча ва бугун. Oriental Art and Culture, (IV (1)), 46-49.

22. Boltaboeva, U., Andunazarov, Z., \& Tursunova, G. (2020). Importance of tongue twisters and proverbs in overcoming speech defects. Journal of Advanced Research in Dynamical and Control Systems, 12(2), 2902-2905.
23. Болтабоева, У. (2020). Нутқ санъатининг ўзига хос хусусиятлари: муаммо ва ечимлар. Oriental Art and Culture, (I (2)), 26-32.

24. Boltaboeva, U. (2019). Using Oral Folk Art Methods in Improving Speech Technology. Eastern European Scientific Journal, (1).

25. Boltaboeva, U., Sh, U., \& Rahmonova, N. (2019). Creative person-the role of live word in educating an actor. European Journal of Arts, (3).

26. Boltaboyeva, U., Rakhmonova, N., \& Usmonov, S. (2020). Characteristics of speech Art: problems and solutions. ACADEMICIA: An International Multidisciplinary Research Journal, 10(4), 559-567.

27. Tursunova, G., \& Karimov, B. (2020). Factors that should be considered in musical theater actors education. ACADEMICIA: An International Multidisciplinary Research Journal, 10(11), 57-61.

28. Tursunova, G. (2021). BALET RAQS SAN'ATINING O'RNI VA TARIXIY TARAQQIYOTI. Oriental Art and Culture, (6).

29. Tursunova, G., \& Karimov, B. (2020). PEARLS OF UZBEK NATIONAL DANCE. International Engineering Journal For Research \& Development, 5(Conference), 4-4.

30. Yunusov, G. X., Juraev, I., \& Ahmedov, R. The European Journal of Arts, Issue $1 / 2020$.

31. Yunusov, G., Ahmedov, R., Jurayev, I., \& Yuldasheva, S. (2021). A Look At The Folklore of Fergana Valley or History of A Song in The Series of Tanovar. Annals of the Romanian Society for Cell Biology, 
CURRENT RESEARCH JOURNAL OF PEDAGOGICS 2(11): 54-59, November

2021 DOI: https://doi.org/10.37547/pedagogics-crjp-02-11-12

ISSN 2767-3278

(C)2021 Master Journals

Crossref do) 81 Google

Accepted $25^{\text {th }}$ November, 2021 \& Published $30^{\text {th }}$ November, 2021

25(6), 2225-2232.

32. Yunusov, G., Juraev, I., \& Ahmedov, R. (2020). A LOOK AT THE REGIONAL SEASONAL FOLKLORE AND THEIR ORIGIN. THE ROLE AND IMPORTANCE OF FOLKLORE IN THE DEVELOPMENT OF DANCE ART. European Journal of Arts, (1), 121-124.

33. Юлдашева, С. Н. (2020). СОЦИОЛОГИЧЕСКОЕ ИССЛЕДОВАНИЕ ЧИТАТЕЛЬСКОЙ АУДИТОРИИ. ТИПОЛОГИЯ ЧИТАТЕЛЕЙ. Oriental Art and Culture, (V).

34. Sohibaxon, Y. (2021). O'ZBEKISTONDA KUTUBXONACHILIK SOHASINING RIVOJI. Oriental Art and Culture, (7), 260-268.

35. Yunusov, G., Ahmedov, R., Jurayev, I., \& Yuldasheva, S. (2021). A Look At The Folklore of Fergana Valley or History of A Song in The Series of Tanovar. Annals of the Romanian Society for Cell Biology, 25(6), 2225-2232.

36. Yuldasheva, S., Habibjonov, I., \& Haydarov, A. (2020). Librarianship in the formation of book reading. Journal of Advanced Research in Dynamical and Control Systems, 12(2), 2925-2927.

37. Юлдашева, С. (2019). Китоб мутолаасини шакиллантиришда кутубхоначилик фаолияти. Oriental Art and Culture, (IV (1)), 59-62.

38. Yunusov, G., Ahmedov, R., Jurayev, I., \& Yuldasheva, S. (2021). A Look At The Folklore of Fergana Valley or History of A Song in The Series of Tanovar. Annals of the Romanian Society for Cell Biology, 25(6), 2225-2232.

39. Yuldasheva, S., \& Madumarova, M. (2020). TASKS AND CONTENT OF BIBLIOGRAPHIC WORKS. European Journal of Arts, (1),
148-152.

40. Yunusov, G. X., Juraev, I., \& Ahmedov, R. The European Journal of Arts, Issue $1 / 2020$.

41. GofirjonYunusov, R. A., Jurayev, I., \& Yuldasheva, S. (2021). A Look at the Folklore of Fergana Valleyor History of a Song in the Series of Tanovar. Annals of the Romanian Society for Cell Biology, 25(6), 2822-2827.

42. Yunusov, G., Juraev, I., \& Ahmedov, R. (2020). A LOOK AT THE REGIONAL SEASONAL FOLKLORE AND THEIR ORIGIN. THE ROLE AND IMPORTANCE OF FOLKLORE IN THE DEVELOPMENT OF DANCE ART. European Journal of Arts, (1), 121-124.

43. Talaboyev, A., Yunusov, G., \& Ahmedov, R. (2020). Local methods of traditional singing. Journal of Advanced Research in Dynamical and Control Systems, 12(2), 2916-2920.

44. Yunusov, G., Ahmedov, R., Jurayev, I., \& Yuldasheva, S. (2021). A Look At The Folklore of Fergana Valley or History of A Song in The Series of Tanovar. Annals of the Romanian Society for Cell Biology, 25(6), 2225-2232.

45. Yunusov, G., Juraev, I., \& Ahmedov, R. (2020). A LOOK AT THE REGIONAL SEASONAL FOLKLORE AND THEIR ORIGIN. THE ROLE AND IMPORTANCE OF FOLKLORE IN THE DEVELOPMENT OF DANCE ART. European Journal of Arts, (1), 121-124.

46. Usmonov, S., \& Talaboyev, A. (2021). Work of the director with an artist. ACADEMICIA: An International Multidisciplinary Research Journal, 11(3), 2407-2410.

47. Талабоев, А. (2019). Мақом санъатида 
CURRENT RESEARCH JOURNAL OF PEDAGOGICS 2(11): 54-59, November

2021 DOI: https://doi.org/10.37547/pedagogics-crjp-02-11-12

ISSN 2767-3278

(C)2021 Master Journals

Crossref dol 81 Google

Accepted 25th November, 2021 \& Published 30th November, 2021

сўзнинг уцрни. Oriental Art and Culture, (IV (1)), 25-28.

48. Talaboev, A., Akbarov, T., \& Haydarov, A. (2020). SONG PERFORMING IN TRADITIONAL PERFORMING ARTS: PAST AND PRESENT TIM. European Journal of Arts, (1), 85-88.

49. Dadaboev, Y., \& Dehqonov, R. Hordo Structures in Central Asian Architecture.

50. Дехқонов, Р. (2020). СОҒЛОМ АВЛОДЛАРНИ ШАКЛЛАНТИРИШДА ХАЛҚ ЎЙИНЛАРИ АНЪАНАЛАРИНИНГ ТУТГАН ЎРНИ. Oriental Art and Culture, (V).

51. Utaganov, R., Dehqonov, R., \& Tuxtasinov, M. (2020). MAIN ADVANTAGES OF TEACHING METHODS IN ARTS. European Journal of Arts, (2), 146-148. 